\title{
Kimura's disease: a diagnostic dilemma
}

\author{
Vishesh Yadav, ${ }^{1}$ Ankur Bhagat, ${ }^{2}$ Shreeyam Mohapatra, ${ }^{3}$ Karandeep Singh Arora ${ }^{4}$
}

\begin{abstract}
${ }^{1}$ Oral Medicine and Radiology, Shree Guru Gobind Singh Tricentenary University Faculty of Dental Sciences, Gurgaon, Haryana, India

${ }^{2}$ Oral Medicine and Radiology, Rayat Bahra Dental College \& Hospital, Mohali, Punjab, India ${ }^{3}$ Oral Medicine and Radiology, SCB Dental College and Hospital, Cuttack, Odisha, India ${ }^{4}$ Oral Medicine and Radiology, Maharishi Markandeshwar College of Dental Sciences \& Research, Mullana, Ambala, Harayana, India
\end{abstract}

Correspondence to Dr Karandeep Singh Arora drkaranarora@yahoo.com

Accepted 13 February 2019

\section{DESCRIPTION}

A 42-year-old male patient came to the department with multiple swellings on his face. Ten years prior to his presentation at our department, he underwent surgical excision at another hospital for similar swellings. However, as per the history the swelling reoccurred immediately within a month after surgery which gradually increased in size. The medical history of the patient did not reveal any significant history. On clinical examination (figure 1), a solitary swelling with bi-lobed appearance was appreciable, which may be due to the presence of indentation at the middle of lower eyelid of the right eye originating from medial aspect of supraorbital region and nasal bridge upto the infraorbital region measuring approximately $4 \times 2 \mathrm{~cm}$ in dimension. The edges of the swelling were clearly defined with no visible pulsations seen over the surface. The skin overlying the swelling was reddish in colour, stretched and glossy in appearance. On palpation swelling was afebrile, non-tender with smooth surface and well-defined margins. Further, it was soft in consistency, non-fluctuant, non reducible and compressible. Another diffuse swelling was seen over lower left portion of the face extending superiorly $2 \mathrm{~cm}$ below the infraorbital margin and inferiorly extending upto the inferior border of the mandible. Anteroposteriorly involving lateral wall of the nose up to the anterior border of the ramus of the mandible, measuring approximately $5 \times 3 \mathrm{~cm}$ in dimension. In view of the above findings a clinical diagnosis of vascular malformation/lymphangioma was made.

On investigating, his blood parameters revealed raised eosinophilia. The others systemic investigation were unremarkable. Ultrasonography (figure 2) revealed ill defined heterogeneously hyperechoic areas with multiple small vascular channel in it showing flow venous and low resistance arterial flow pattern in it. A soft tissue MRI scan (figure 3) revealed, diffuse asymmetric thickening of subcutaneous tissue of face involving cheek and bilateral submandibular region with presence of ill defined

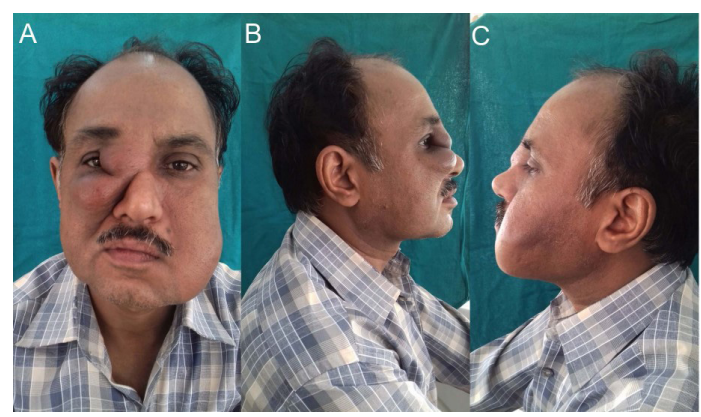

Figure 1 Multiple swellings on the face.

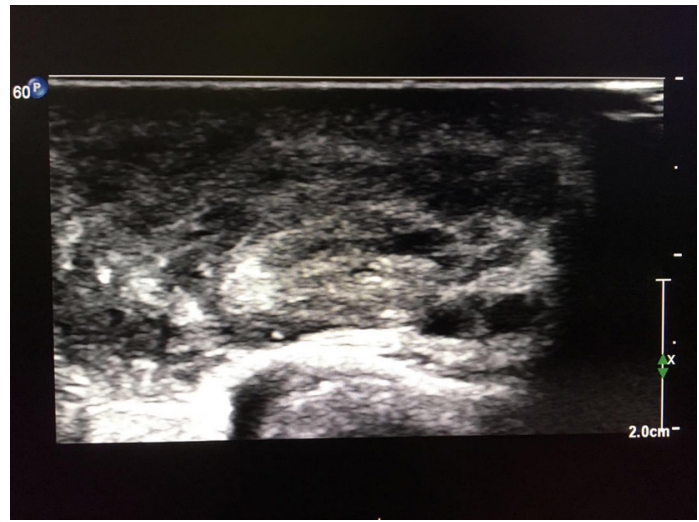

Figure 2 Ultrasonography image.

infiltrative $T_{1}$ hypointense and $T_{2}$ fat hyperintense soft tissue showing moderate homogenous post contrast enhancement. Also, similar lobulated moderately enhancing subcutaneous soft tissue is seen in right periorbital region and in pre-septal space measuring approximately $6.4 \times 3.6 \mathrm{~cm}$ in size extending upto the dorsum of nose and right frontal subcutaneous plain. Bilateral submandibular and parotid gland were bulky and revealed mild homogenous post contrast enhancement. Also, histopathological examination of the skin biopsy from left cheek revealed, dense chronic inflammatory cell infiltrate with excess of eosinophils. The investigative findings were suggestive in making a final diagnosis of Kimura's disease.

Kimura's disease also known as eosinophillic lymphogranuloma, is a rare benign inflammatory disorder of unknown aetiology. ${ }^{1}$ A very few cases have been listed in literature and which add to the diagnostic dilemma of the disease as its features often confusing and overlap with other entities. The most common disease that resembles Kimura's disease is angiolymphoid hyperplasia with eosinophilia. It is interesting to note that both the diseases have a predilection for the head and neck region and clinically present as subcutaneous mass having lymphoid infiltrates along with eosinophils
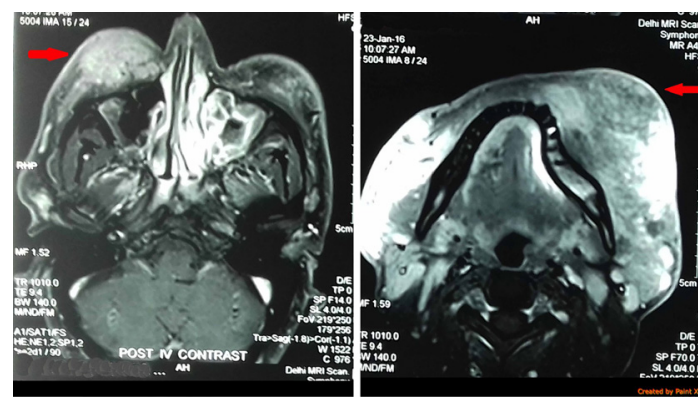

Figure 3 MRI scans Images of the swellings. 
and vascular proliferation. Kimura's disease was identified as a different identity by Rosai et $a$. $^{2}$ Other differential diagnosis includes reactive lymphadenopathy, angioma/lymphangiom/ hemangioma, lymphoma, salivary gland tumour, nodal metastatsis, Kikuchi disease and Mikulicz's disease. ${ }^{34}$

The diagnosis can be aided by Ultrasonography/CT/MRI scans which can help in delineating the extent and also in evaluating

\section{Learning points}

- The diagnosis of Kimura's Disease can be difficult and misleading as patients with this disease are often evaluated using avoidable procedures by just not being aware of KD.

- Here we have tried to put forward the clinical and investigative features of Kimura's disease, which usually pose challenge in diagnosing this condition.

- Though it is rare, one has to be aware of it as its recurrence rate is very high following any kind of treatment.

- In our case, patient had undergone prior surgery but it reoccurred within 1 month afterwards, following which patient visited our department with swelling on the face after 10 years. the progression of the disease. The first line of treatment includes surgical excision with steroid therapy (systemically administered). Cases where size of lesion is too large may be treated using radiation therapy.

Contributors VY was responsible for managing the case from history taking to treatment. $A B$ and $S M$ were responsible for radiographic interpretation and initial proposal of the manuscript. KSA was responsible for data collection, data compilation, rough and final draft of the manuscript. Further, the manuscript was reviewed by all the authors before submission.

Funding The authors have not declared a specific grant for this research from any funding agency in the public, commercial or not-for-profit sectors.

Competing interests None declared.

Patient consent for publication Obtained.

Provenance and peer review Not commissioned; externally peer reviewed.

\section{REFERENCES}

1 Larrochec C, Bletry O. Kimura's disease. Orphanet encyclopedia. 2005 http://www. orpha.net/data/patho/GB/uk-kimura.pdf.

2 Rosai J, Gold J, Landy R. The histiocytoid hemangiomas. A unifying concept embracing several previously described entities of skin, soft tissue, large vessels, bone, and heart. Hum Pathol 1979;10:707-30.

3 Swarnkar M, Agarwal A. Kimura's disease: a case report and review of literature. J Krish Inst Med Sci Univ 2017;6:118-20.

4 Kaneko K, Aoki M, Hattori S, et al. Successful treatment of Kimura's disease with cyclosporine. J Am Acad Dermatol 1999;41:893-4.

Copyright 2019 BMJ Publishing Group. All rights reserved. For permission to reuse any of this content visit

https://www.bmj.com/company/products-services/rights-and-licensing/permissions/

BMJ Case Report Fellows may re-use this article for personal use and teaching without any further permission.

Become a Fellow of BMJ Case Reports today and you can:

- Submit as many cases as you like

- Enjoy fast sympathetic peer review and rapid publication of accepted articles

- Access all the published articles

- Re-use any of the published material for personal use and teaching without further permission

For information on Institutional Fellowships contact consortiasales@bmjgroup.com

Visit casereports.bmj.com for more articles like this and to become a Fellow 